\title{
The moderating role of organizational culture on the effect of organizational justice on organizational citizenship behavior
}

\author{
IRA MARDIYANTI'1 and SUHARNOMO1, \\ ${ }^{1}$ Department of Management, Faculty of Ecomonics and Business, Universitas Diponegoro, Indonesia
}

\begin{tabular}{ll}
\hline Abstract & The main objective of this study is to examine the effect of distributive justice and \\
procedural justice on organizational citizenship behavior (OCB) with organizational culture \\
as a moderating variable. The data in this study were collected from questionnaires \\
distributed to 94 permanent employees of PT Telekomunikasi Indonesia (Telkom) Tbk. \\
Regional Division IV. Hypotheses testing shows that distributive and procedural justice \\
positively affects OCB. Organizational culture is also found to be the moderator on the \\
effect of procedural justice on OCB. However, our prediction that organizational culture \\
could be the moderator on the effect of distributive justice on OCB is not supported. \\
Further results and discussion are explained.
\end{tabular}

Keywords

distributive justice, procedural justice, organizational citizenship behavior (OCB), organizational culture, ethical behavior

\section{INTRODUCTION}

In the last few decades, organizational citizenship behavior (OCB) has received considerable attention among scholars and practitioners because its significant contribution to the organizational effectiveness (Erkutlu, 2011). OCB which could be reflected in some behavior such as talking positively about their organization, helping others, and performing well beyond expectation is the outcome of such satisfied feeling of individuals to their organization. In other word, OCB is individual expression to re-compensate the positive feelings they got from the company (Robbins, 2006). One of the factors that could be the predictor of OCB is justice-based managerial system (Pratiwi, 2013). Therefore, the first objective of this study is to examine the effect of distributive and procedural justice on OCB.

Our study also proposes organizational culture as moderating variable on the effect of distributive and procedural justice on OCB. We propose organizational culture as a moderating variable because it has a strong impact on employee behavior, (Khan et al, 2011), and one of the behaviors is OCB (Pratiwi, 2013). Furthermore, to develop our model, we also propose a notion that the relationship between distributive and procedural justice on OCB could be through another variable, and we propose ethical behavior.

To examine our hypotheses, we selected PT TELKOM Tbk Regional Division IV as our research object. The rationale of the selection is based on the fact that recently PT TELKOM Tbk has made some changes in order to improve the company's effectiveness, increase services performance to consumers, and maintain organization's justice system. One of the indicators of organizational justice perceptions was the amount of benefits received by employees.

\section{HYPOTHESES DEVELOPMENT}

\section{Distributive justice, procedural justice, and ethical behavior}

Jones and Kavanagh (1996) argued that employee ethical behavior is a "pull down" because of an unethical behavior conducted by managers to co-workers. The research results of Chen McCain, Tsai, and Bellino (2010) conducted at the "Casino Industry" suggested that distributive justice positively 
affect employees' ethical behavior, and distributive justice has the strongest positive and significant effect on job satisfaction and OCB.

According to the second hypothesis of Chen McCain et al. (2010), there is a positive relationship between procedural justice and ethical behavior, as the immediate effect of procedural justice on ethical behavior is slightly greater than that of distributive justice. Thus, the result of the data processed from 520 employees of the "Casino Industry" revealed that procedural justice is more important than distributive justice in determining the ethical behavior of "Casino Industry" employees.

\section{H1: Distributive justice has a positive} effect on ethical behavior.

H2: Procedural justice has a positive effect on ethical behavior.

\section{Ethical behavior and OCB}

Loucks (1987) indicated that company's ethical behavior depends on employee's ethical behavior. Employees behave ethically refers to certain morals such as Wiley's principles of justice and trust (1995). Furthermore, employee's ethical behavior is influenced by the existence of company's policies, procedures, and fair decisionmaking (Baker et al, 2006). Therefore, when a company treated employees very fairly, employees would behave ethically and showed an attitude of organizational citizenship behavior, as employee's ethical behavior could affect employee OCB within a company.

H3: Ethical behavior has a positive effect on $O C B$.

\section{Distributive justice, procedural justice, and OCB}

Erkutlu (2011) showed that there is a weak relationship between distributive justice and OCB for higher organization in a team orientation. The research result of Ince \& Gul (2011) confirmed that the type of justice that most determine OCB is distributive justice.

OCB is a better predictor of procedural justice than distributive justice (Konovsky and Pugh, 1994). Greenberg (2005) indicated that people would be more attentive to the organizations they work for when they believe that the organizations have treated them fairly. Jex in Lock (2005) explained that people who participate in OCB has had cognitive evaluations about the fairness of employees' treatment by the organization. Employees are evaluated their work situation by comparing their inputs to the organization to the results they received. Thus, an organization providing fair and equitable treatment would have employees who wish to compensate it by implementing a good OCB. In addition, lqbal, Aziz, and Tasawar (2012) argued that procedural justice has a strongly positive influence on OCB.

Given this situation, when companies are fair and have procedural fairness, employees will feel more satisfied that make them show their behaviors beyond job descriptions, remuneration, and formal reward systems, and certainly increase OCB within the company (Pratiwi, 2013).

H4: Distributive justice has a positive and significant effect on $O C B$.

H5: Procedural justice has a positive and significant effect on OCB.

\section{Organizational culture, distributive justice, and ethical behavior}

Organizational culture that has been formed, accepted, and well implemented by all members of the company would easily create organizational justice, especially distributive justice. Distributive justice is justice that its results can be perceived by the organization (Cohen-Charash and Spector, 200) based on evaluations of employee perceptions whether the results are distributed fairly or proportionally to what they have done (Gilliland, 1994). For example, salary levels, rewards, and promotions, as well as quality and quantity of workload (Niehoff and Moorman, 1993; Walster et al., 1978). Good organizational culture would create a fair justice organization for all members of the organization. When an organization had an organizational culture and organizational justice, employee ethical behavior within the organization would also be created.

H6: Organizational culture moderates the effect of distributive justice on ethical behavior. 


\section{Organizational culture, procedural justice, and ethical behavior}

Good organizational culture would affect the creation of organizational justice. As stated in hypothesis six, hypothesis seven explained about procedural justice. Procedural justice is justice referring to formal organizational procedures such decision-making and clarity of the procedures (Greenberg, 1990; Niehoff and Moorman, 1993; Gilliland, 1994; Johnson, 2007). According to Greenberg (1994), employees have perceived that they have procedural justice when the supervisor explains their decision. justice in the organization significantly affects employees' ethical behavior. When employees felt being treated justifiably by organization, they tend to seek opportunities to balance everything by increasing their own benefits for the company (Trevino and Weaver, 2001). Thus, when employees are treated fairly, they are more willing to prioritize the interests of groups or organizations than their individual interests (Lind and Tyler, 1988).

H7: Organizational culture moderates the effect of procedural justice on ethical behavior.

\section{Organizational culture, distributive justice, and OCB}

Distributive justice is perception of employees toward organizational benefits and resources (Fitz Gerald, 2002). This type of justice is focused on the level of distribution of rewards and punishment (Nirmala and Akhilesh, 2006), and employees perceptions about the distribution organization's resources and benefits (Blakely et al, 2005). Distributive justice explains how to treat individual equally or differently according to ethical and objective criteria (Wang et al, 2010). When distributive justice has been applied in organizations and employees feel that the justice exists, employees will demonstrate the organizational citizenship behavior (OCB). Organ (1988) defines the organizational citizenship behavior as individual's voluntary actions that are not clearly defined in the formal reward and punishment within organizational system but support the effectiveness and efficiency of the organization as a whole. The procedural justice and OCB are influenced by organizational culture created within the organization.
H8: Organizational culture moderates the effect of distributive justice on OCB.

\section{Organizational culture, procedural justice, and OCB}

Organizational justice created citizenship behavior besides distributive justice and procedural justice. Procedural justice is a perception of fairness associated with the decision-making process (Konovsky, 2000). Decision making in an organization is also influenced by the organizational culture style applied by an organization. Smith, Organ and Near (1983) further explained that a good organizational culture will create a good, wise, and fair justice (procedural justice)under which all employees fell secure and, as a result, they will show organizational citizenship behavior; behavior describing OCB as individual whose contributions are recognize as achievements.

H9: Organizational culture moderates theeffect of procedural justice on $O C B$

\section{Organizational culture, ethical behavior, and OCB}

Organizational culture referred to a shared meaning system held by members that differentiate the organization from other organizations. Organizational culture formed within an organization would influence the establishment of ethics in the organization and the organization citizenship behavior of the employees. Good organizational culture would create ethical behavior and the ethical behavior of the employees would create OCB.

H10: Organizational Culture moderates the effect of Ethical Behavior on OCB.

\section{METHODS}

\section{Data collection}

To test the proposed model, initial interview with HR managers and 94 employees of PT TELKOM Tbk Regional Division IV using questionnaire based literature review was carried out. The result was revised based on issues identified and approved by HR managers at PT TELKOM Tbk. to make sure 
that the questions really reflected the objectives investigated.

Table 1.

Demographic Profile of Respondents

\begin{tabular}{llll}
\hline Profile & Category & $\begin{array}{l}\text { Frequ } \\
\text { ency }\end{array}$ & $\%$ \\
\hline Gender & Male & 58 & $61.7 \%$ \\
& Female & 36 & $38.3 \%$ \\
\hline Age & $20-29$ & 12 & $12.8 \%$ \\
& $30-39$ & 21 & $22.3 \%$ \\
& $40-49$ & 14 & $14.9 \%$ \\
& $\geq 50$ & 47 & $50.0 \%$ \\
\hline Work & $1-3$ & 3 & $3.2 \%$ \\
Tenure & $3-5$ & 5 & $5.3 \%$ \\
& $>5$ & 86 & $91.5 \%$ \\
\hline Education & High School & 21 & $22.3 \%$ \\
& Diploma & 15 & $16.0 \%$ \\
& Undergraduate & 58 & $61.7 \%$ \\
\hline
\end{tabular}

There were 100 questionnaires distributed to permanent employees, but only 94 that returned and could be analyzed. As shown in Table 1, of the 94 respondents who returned the questionnaire, the majority were male $(61,7 \%)$. Most of the respondents are above 50 years old $(50 \%)$ and have more than 5 years work tenure $(91,5 \%)$. Meanwhile, the highest degree achieved by most of the respondents is undergraduate degree $(61,7$ $\%)$

\section{Measurement}

Distributive and procedural justice was measured using 4 and 6 statements respectively, while OCB was measured using 8 statements. Meanwhile, organizational culture and ethical behavior was measured using 5 statements for each of them. All construct were measured using seven points of Likert scale, ranging from $1=$ strongly disagree to $7=$ strongly agree

\section{RESULTS AND DISCUSSIONS}

\section{Validity and reliability test}

Before testing our hypotheses, we conducted validity and reliability test to our measurements. The validity test was measured using Pearson product moment while the reliability test was measured using Cronbach's alpha. The results of validity and reliability test shows that all measurements employed in this study is valid and reliable
(Cronbach's alpha score ranging from 0.609 to 0.713 ).

\section{Path analysis}

\section{The effect of distributive justice and procedural justice on ethical behavior}

The result of linear regression test shows that distributive justice positive and significantly affect ethical behavior $(\beta=0.553$; $\mathrm{p}<0,05)$. Thus, hypotheses 1 which suggest that distributive justice positively affect ethical behavior is supported. It is consistent with the previous research by Chen McCain et al. (2010).

The result also shows that procedural positive and significantly affect ethical behavior $(\beta=0.374 ; \quad p<0,05)$. Therefore, hypotheses 2 which state that procedural justice positively affect ethical behavior is supported. This finding supports the previous research by Chen McCain et al. (2010).

\section{The effect of distributive justice, procedural justice, and ethical behavior on $O C B$}

The result shows that distributive justice has positive and significant effect on OCB $(\beta=0.532 ; p<0,05)$. Thus, hypotheses 3 is supported, consistent with previous research by Jeffrey and Weisberg (2002). The result also suggest that procedural justice has positive and significant effect on OCB $(\beta=0.585 ; p<0,00)$. Therefore, hypotheses 4 is supported, in line with studies conducted by Erkutlu (2011). Another result shows that ethical behavior has positive and significant effect on OCB $(\beta=0.488 ; p<0,05)$. Thus, hypotheses 5 is supported, consistent with previous findings by Erkutlu (2011) and Chen McCain et al. (2010).

\section{Test of moderation effect}

\section{Model 1}

The result shows that the interaction effect of distributive justice and organizational culture positive but not significantly affect ethical behavior $\quad(\beta=0.872 ; \quad p>0,05)$. Thus, hypotheses 6 which stated that organizational culture moderates the effect of distributive justice on ethical behavior is not supported. 
Figure 1.

Result of path analysis

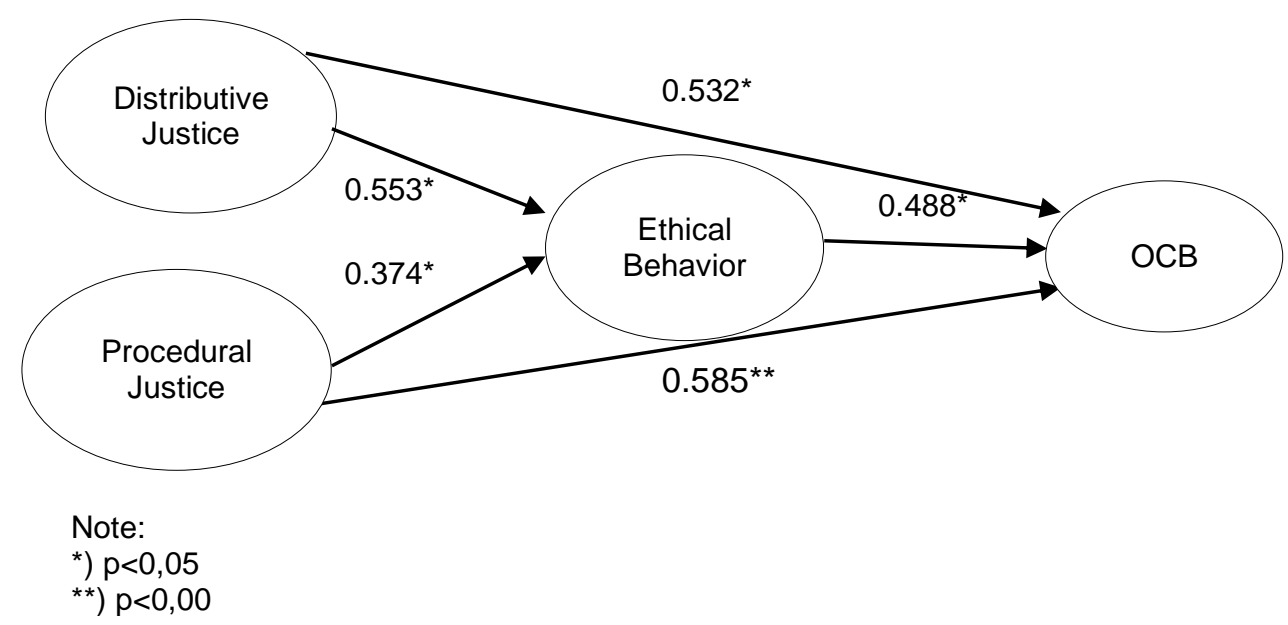

\section{Model 2}

The result shows that the interaction effect of procedural justice and organizational culture positive and significantly affect ethical behavior $\quad(\beta=1.352 ; \quad p<0,05)$. Thus, hypotheses 7 which stated that organizational culture moderates the effect of procedural justice on ethical behavior is supported. It is consistent with previous result found by Khan et al. (2015).

\section{Model 3}

The result shows that the interaction effect between distributive justice and organizational culture positive but not significantly affect OCB $(\beta=0.038 ; p>0,05)$. Thus, hypotheses 8 which stated that organizational culture moderates the effect of distributive justice on OCB is not supported.

\section{Model 4}

The result shows that the interaction effect of procedural justice and organizational culture positive and significantly affect $\mathrm{OCB}$ $(\beta=1.105 ; \quad p<0,05)$. Thus, hypotheses 9 which stated that organizational culture moderates the effect of procedural justice on OCB is supported. It is in line with previous finding in study conducted by Khan et al. (2015

\section{Model 5}

The result shows that the interaction effect of ethical behavior and organizational culture negative and not significantly affect OCB $(\beta=-0.331 ; p<0,05)$. Thus, hypotheses 10 which stated that organizational culture moderates the effect of ethical behavior on OCB is not supported.

\section{CONCLUSION}

The main objective of this study is to examine the moderating effect of organizational culture on the effect of distributive and procedural justice on OCB. Our findings support the notion that distributive and procedural justice positively affect OCB. Our study also find that organizational culture could be the moderator on the effect of distributive and procedural justice on OCB.

Those results suggest that in order to improve the level of employees' OCB, the decision makers at organization should maintain the distributive justice such as payment and praise and procedural justice such as the consistency of process to all of the employees. The results also suggest that in order to foster the positive effect of distributive justice and procedural justice on OCB, managers could strengthen the organizational culture through the socialization of organizational values.

We acknowledge that our study has some limitations. One of them is the limited sample in our study. Therefore, we recommend for 
other researcher to explore the relationship between organizational justice, OCB, ethical behavior, and organizational culture in a broader object. Another limitation of our study is the data collection method that use cross section technique. Thus, future study could conduct the study using longitudinal method.

\section{REFERENCES}

Bakhshi, Arti, Kuldeep Kumar, and Ekta Rani. 2009. "Organizational Justice Perceptions as Predictor of Job Satisfaction and Organization Commitment". International Journal of Business and Managemen, Vol.4, No.9, pp.145-154.

Erkultu, Hakan. 2011. "The Moderating role of organizational culture in the relationship between organizational justice and organizational citizenship behaviors". Leadership\&Organization Development Journal, Vol.32, No.6, pp.532-554.

Faizah, Siti. 2008. "Pengaruh Persepsi Keadilan, Kepuasan Kerja, dan Komitmen Organisasi terhadap Organizational Citizensip Behavior (OCB)". Tesis tidak dipublikasikan, Universitas Diponegoro.

Fuzan. 2015. "Pengaruh Religiusitas Dan Ethical Climate Terhadap Ethical Behavior". Jurnal Modernisasi , Vol.11, No.3, pp.187-202.

Ghozali, Imam. 2007. Aplikasi Analisis Multivariate dengan program SPSS. Semarang : Badan Penerbit Universitas Diponegoro.

Ince, Mehmet and Hasan Gul. 2011. "The Effect of Employees' Perceptions of Organizational Justice on Organizational Citizenship Behavior: An Application in Turkish Public Institutions". International Journal of Business and Management, Vol.6, No.6, pp.134-149.

Jeffrey, Kantor and Jacob Weisberg. 2002. "Ethical attitudes and Ehical behavior are manager role models?". International Journal of Manpower, Vol.23. No.8, pp.687-703.

Khan, Sofiah Kadar and Mohd Zabid Hj Abdul Rashid. 2015. "The Mediating Effect of Organization Commitment in the Organization Culture, Leadership and Organization Justice Relationship with Organization Citizenship Behaviour: A study of Academics in Private Higher Learning Institutions in Malaysia". International Journal of Recent Advances in Organizational Behaviour and Decision Sciences (IJRAOB), Vol.1, No.2, pp.335359.

McCain, Shiang-Lih Chen et al,. 2010. "Organizational Justice, employees' ethical behavior, and Job satisfaction in the casino industry. "International Journal of Contempory Hoapitality Management, Vol.22, No.7, pp. 992-1009.

Nurfianti, Agustin dan Handoyo, Seger.2013. "Hubungan Antara Keadilan Distributif dan Perilaku KerjaKontraproduktif dengan Mengontrol Leader Member Exchange (LMX)". Jurnal Psikologi Industri dan Organisasi, Vol.02, No.03, pp.183-190.

Pratiwi, Indhira. 2013. "Analisis Pengaruh Budaya Organisasi dan Keadilan Organisasi terhadap Organizational Citizenship Behavior (OCB) dengan Komitmen Organisasional sebagai Variabel Intervening (studi pada karyawan kantor pt telekomunikasi indonesia tbk. Divisi Regional IV wilayah Jateng dan DIY)". Skripsi Tidak Dipublikasikan, Manajemen Fakultas Ekonomika dan Bisnis Universitas Diponegoro.

Robbins, Stephen P. and Judge A. 2006. Perilaku Organisasi. Bahasa Indonesia ed. PT Indeks Kelompok Gramedia.

Robbins, Stephen P. and Judge A, Timothy. 2012. Organizatioanal Behavior. 15th ed. p. cm. United States of America : Pearson Education, Inc.

Turgut, Hakan, Ismail Tokmak, and Cem Gucel. 2012. "The Effect Of Employees Organizational Justice Perceptions On Their Organizational Commitment: A University Sample". International Journal Of Business And Management Studies, Vol.4, No.2, pp.21-30. 